\section{A LiDAR-based approach for a multi-purpose characterization of Alpine forests: an Italian case study}

\author{
Giorgio Alberti ${ }^{(1,2)}$, Francesco Boscutti ${ }^{(1)}$, Francesco Pirotti ${ }^{(3)}$, \\ Cristina Bertacco ${ }^{(1)}$, Giuseppe De Simon ${ }^{(1)}$, Maurizia Sigura ${ }^{(1)}$, \\ Federico Cazorzi ${ }^{(1)}$, Pierluigi Bonfanti ${ }^{(1)}$
}

Several studies have verified the suitability of LiDAR for the estimation of forest metrics over large areas. In the present study we used LiDAR as support for the characterization of structure, volume, biomass and naturalistic value in mixed-coniferous forests of the Alpine region. Stem density, height and structure in the test plots were derived using a mathematical morphology function applied directly on the LiDAR point cloud. From these data, digital maps describing the horizontal and vertical forest structure were derived. Volume and biomass were then computed using regression models. A strong agreement (accuracy of the map $=97 \%$, Kappa Cohen $=94 \%$ ) between LiDAR land cover map (i.e., bare soil, forest, shrubs) and ground data was found, while a moderate agreement between coniferous/broadleaf map derived from LiDAR data and ground surveys was detected (accuracy $=73 \%$, Kappa Cohen $=60 \%$ ). An analysis of the forest structure map derived from LiDAR data revealed a prevalence of even-age stands $(66 \%)$ in comparison to the multilayered and uneven-aged forests $(20 \%)$. In particular, the even-age stands, whether adult or mature, were overwhelming (33\%). A moderate agreement was then detected between this map and ground data (accuracy $=68 \%$, Kappa Cohen $=58 \%$ ). Moreover, strong correlations between LiDAR-estimated and ground-measured volume and aboveground carbon stocks were detected. Related observations also showed that stem density can be rightly estimated for adult and mature forests, but not for younger categories, because of the low LiDAR posting density $\left(2.8\right.$ points $\left.\mathrm{m}^{-2}\right)$. Regarding environmental issues, this study allowed us to discriminate the different contribution of LiDAR-derived forest structure to biodiversity and ecological stability. In fact, a significant difference in floristic diversity indexes (species richness - R, Shannon index - H') was found among structural classes, particularly between pole wood $\left(R=15\right.$ and $\left.H^{\prime}=2.8 ; P<0.01\right)$ and multilayer forest $\left(\mathrm{R}=31\right.$ and $\left.\mathrm{H}^{\prime}=3.4\right)$ or thicket $\left(\mathrm{R}=28\right.$ and $\left.\mathrm{H}^{\prime}=3.4\right)$ where both indexes reached their maximum values.

Keywords: Lorey's Mean Height, Tree Volume, Carbon Stocks, Biodiversity, Species Richness, LiDAR

\section{Introduction}

In the last decade, applied environmental sciences have undergone a radical change with the emergence of new technologies related to the retrieval and processing of spatial data. In particular, modern remote sensing techniques, such as Light Detection and Ranging (LiDAR), have been playing an increasingly important role in forest description, from local (e.g., Maltamo et al. 2004) to regional (Naesset \& Gobakken 2008, Saatchi et al. 2011) or global scale (Simard et al. 2011), in terms of tree composition (Reitberger et al. 2008), forest structure (Coops et al. 2007, Pascual et al. 2008, Falkowski et al. 2009), vegetation mapping (Tickle et al. 2006, Verrelst et al. 2009) and stand development (Castillo-Nunez et al 2011). The increased market demand for
(1) Department of Agricultural and Environmental Sciences, University of Udine, v. delle Scienze 206, I-33100 Udine (Italy); (2) MOUNTFOR Project Centre, European Forest Institute, Via E. Mach 1, San Michele a/Adige (Trento - Italy); (3) Land, Environment, Agriculture and Forestry Department, CIRGEO - Interdepartmental Research Center on Cartography Photogrammetry - Remote Sensing and G.I.S., University of Padova, Padua (Italy)

(a) Giorgio Alberti (giorgio.alberti@uniud.it)

Received: Nov 12, 2012 - Accepted: Feb 11, 2013

Citation: Alberti G, Boscutti F, Pirotti F, Bertacco C, De Simon G, Sigura M, Cazorzi F, Bonfanti P, 2013. A LiDAR-based approach for a multi-purpose characterization of Alpine forests: an Italian case study. iForest 6: 156-168 [online 2013-04-08] URL: http://www.sisef.it/iforest/contents/? id=ifor0876-006

\section{Communicated by: Giustino Tonon}

ment with regard to biodiversity and carbon sequestration. In recent decades, several studies and exercises have been carried out to integrate biodiversity issues with forest inventories (Corona et al. 2003), but the debate on the potential role of forest inventories in biodiversity monitoring is still open (Corona et al. 2011). As stand structure plays a key role in deriving biodiversity indicators, LiDAR may be a useful tool in biodiversity management. For example, it appears a quite interesting tool for biodiversity related analysis, such as habitat type classification (Vierling et al. 2008, Collin et al. 2010, Bassler et al. 2011) and species diversity modeling (Gillespie et al. 2004, Vierling et al. 2008). Concerning with carbon sequestration, forests can sequester and store more carbon than all other terrestrial ecosystems (IPCC 2001) and exchange $90 \%$ of total carbon flow between the atmosphere and biosphere (Winjum et al. 1992). Thus, the integration of data from inventories with remote sensing techniques is crucial for an accurate quantification of carbon stocks in forest ecosystems and to monitor the influence of human activities (i.e., forest management, afforestation, deforestation) on these stocks (Kotchenova et al. 2004, Garcia et al. 2010, Beets et al. 2011, Saatchi et al. 2011). LiDAR surveys the three-dimensional (3D) structure of forests by measuring time-offlight of laser pulses reflected from the target. Position and orientation of the scanning device is supplied by the Global Positioning System (GPS) and the Inertial Navigation System (INS - Lim et al. 2003). While filtering operations may be considered a well-es- 
Fig. 1 - Study area.

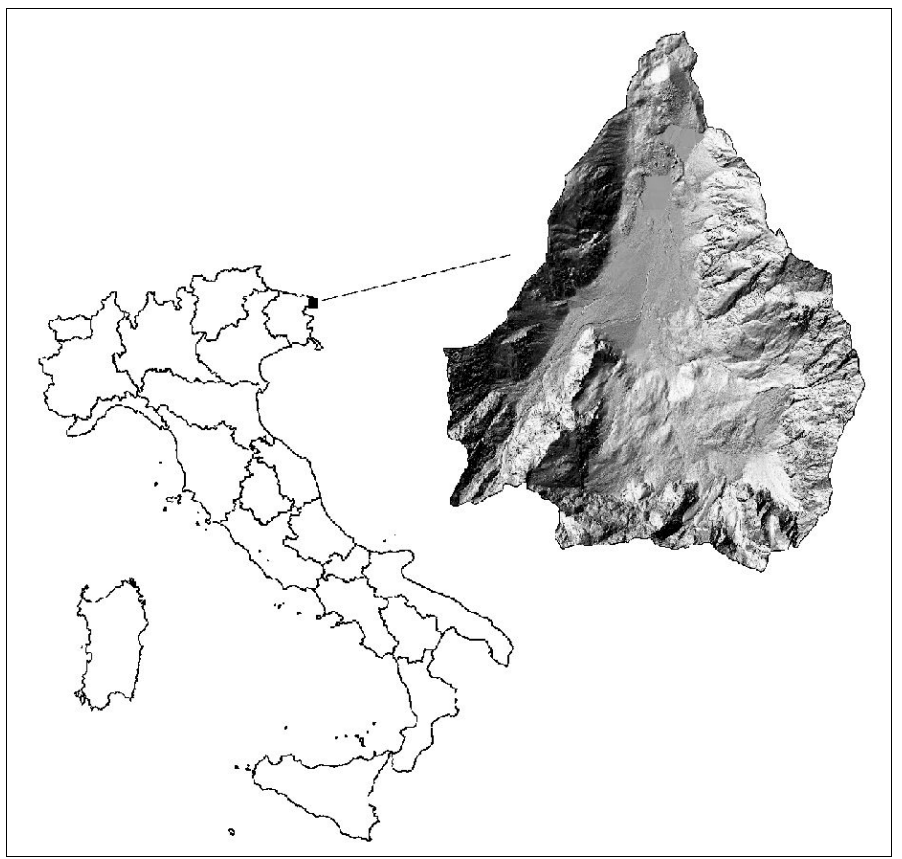

tablished procedure (Barilotti et al. 2006), methods for extracting forest and environmental characteristics from the laser point cloud need, especially in forests with a complex structure, a robust testing and verification phase with ground-truth measurements. Although methods for the extraction of structural and dendrometric characteristics of conifer and broadleaf mature forests are already available (i.e., Barilotti et al. 2007, Abramo et al. 2007), a precise stand characterization can be more problematic in the case of young or uneven-aged multilayered mixed forests because of their intrinsic greater complexity (Corona et al. 2012).

Within this framework, the aims of the present study were: (i) to create and validate digital map of the horizontal and vertical forest structure derived from LiDAR data, (ii) to quantify forest volume and aboveground carbon stocks for each structural class, (iii) to verify LiDAR structural map applicability for forest vegetation characterization (i.e., species diversity and composition) in order to detect forests stands with an high naturalistic value.

\section{Materials and methods}

\section{Materials}

\section{Study area}

The study area is located at Fusine lakes (1 688 ha, 4630'15" N, 133'ㄷ' E - Fig. 1 ), in north-eastern Alps near the Italian border with Slovenia and Austria. The site is characterized by patches of pastures surrounded by spruce forests or spruce, fir and beech mixed forests (Picea abies Karst., Abies alba Mill. and Fagus sylvatica L., respectively - Tab. 1). Mean annual tempera- ture at the Fusine lakes is $7.3^{\circ} \mathrm{C}$ with an absolute maximum of $28^{\circ} \mathrm{C}$ and an absolute minimum of $-27^{\circ} \mathrm{C}$. The area is characterized by a strong annual and daily temperature range $\left(22^{\circ} \mathrm{C}\right)$. Annual rainfall is 1520 $\mathrm{mm}$. Bedrock is mainly dolomite. The study area includes 13 forest compartments belonging to the Regional Government for an area of 665 ha: 7 compartments are forests managed for wood production, 4 are left to natural evolution, 1 compartment has a recreational destination and 1 is unproductive.

\section{LiDAR and ground data acquisition}

LiDAR data were acquired in October $2006(85 \%$ of the study area) and in July 2009 (15\% of the study area) using an Optech ALTM 3100 sensor onboard a helicopter. Average pulse density was 2.8 points per square meter. The flight height was about $1000 \mathrm{~m}$ above ground level, the maximum scan angle was $\pm 18^{\circ}$ and a beam divergence was $0.2 \mathrm{mrad}(\sim 20 \mathrm{~cm}$ at $1000 \mathrm{~m}$ distance). Data were collected on a multi-pulse mode with a maximum of four return echoes registered for each emitted pulse.

Ground-truth points were distributed according to a stratified sampling design. A square grid with cells of $100 \times 100 \mathrm{~m}$ was overlaid on the structural map obtained from LiDAR data (see "Methods") and 37 of them were distributed proportionally to each structural class and then randomly selected. The survey was performed during summer 2010 . Trees were surveyed within a circular plot of $13 \mathrm{~m}$ radius or $4 \mathrm{~m}$ radius depending on their diameter at breast height (DBH $>7.5 \mathrm{~cm}$ and $\mathrm{DBH}<7.5 \mathrm{~cm}$, respectively). In each plot, all standing trees were identified and their DBH were measured. Total height was measured on a subsample of ten trees distributed on different diameter classes.

Within each circular plot, a $100 \mathrm{~m}^{2}$ square subplot was identified for a vegetational survey according to Braun-Blanquet (1964) and Westhoff \& Van Der Maarel (1978). In particular, the following attributes were investigated:

- the cover of each forest layer according to the following scheme: trees $>3 \mathrm{~m}$ high; shrubs $>0.5 \mathrm{~m}$ and $<3 \mathrm{~m}$ in height; herbaceous (all grasses, ferns, and woody species $<0.5 \mathrm{~m}$ in height);

- the proportional cover of each vascular censed species according to Braun-Blanquet (1964) scale, modified by Pignatti (1953).

Flora nomenclature followed Poldini et al. 2001, phytosociological nomenclature was defined according to studies from Marincek et al. (1989), Poldini \& Nardini (1993) and Oberdorfer (2001). The attribution of biological forms (Raunkiær 1934) followed Pignatti (1982).

\section{Methods}

\section{Land cover, coniferous/broadleaf and forest structure maps}

In order to derive land cover, coniferous/ broadleaf and forest structure maps from raw LiDAR data, a individual tree crown approach (ITC) was used (Barilotti et al. 2009). LiDAR data processing was performed using ZEUS software (C) e-Laser srl - http://www. e-laser.it/) in order to classify ground and vegetation points through semi-automatic filtering (Axelsson 2000). A manual check and refinement for areas with complex morphology was also performed. A Digital Terrain Model (DTM) with a $1 \times 1 \mathrm{~m}$ cell resolution was created using filtered ground data and was used to derive individual tree heights using the methods reported by Barilotti et al. (2007). This method is based on a mathematical morphology function derived from the theory proposed by Serra $(1982,1988)$. The function, originally developed to extract the peak elements of a raster image, was adapted to detect spatial position $(\mathrm{x}, \mathrm{y}, \mathrm{z})$ of each tree vertex directly on the point cloud. It was then assumed that the vertex coordinates cor-

Tab. 1 - Land covers in the study area derived from Moland Land Use map.

\begin{tabular}{lrr}
\hline Land use & $\begin{array}{r}\text { Area } \\
\text { (ha) }\end{array}$ & \% \\
\hline Mixed forests & 631 & 37.4 \\
Bare rocks & 471 & 27.9 \\
Heath and scrubs & 261 & 15.5 \\
Coniferous forests & 208 & 12.4 \\
Pastures and grasslands & 77 & 4.6 \\
Water bodies & 23 & 1.4 \\
Hardwood forests & 12 & 0.7 \\
Scrublands & 3 & 0.2 \\
Total & 1688 & - \\
\hline
\end{tabular}


Tab. 2 - Structural classes and structural types as defined by Del Favero et al. (2000) and Barilotti et al. (2009).

\begin{tabular}{|c|c|c|c|}
\hline $\begin{array}{l}\text { Structural } \\
\text { class }\end{array}$ & $\begin{array}{l}\text { Structural } \\
\text { type }\end{array}$ & $\begin{array}{l}\text { Height } \\
\text { (m) }\end{array}$ & Notes \\
\hline \multirow{2}{*}{$\begin{array}{l}\text { Regeneration } \\
\text { phase }\end{array}$} & Regeneration phase 1 & \multirow[b]{2}{*}{$0<\mathrm{h}<3$} & No trees from the higher height class \\
\hline & Regeneration phase 2 & & $\begin{array}{l}\text { are present } \\
\text { Few trees from the higher height class } \\
\text { are present }\end{array}$ \\
\hline \multirow[t]{2}{*}{ Thicket } & Thicket 1 & \multirow[b]{2}{*}{$3<\mathrm{h}<10$} & No trees from the higher height class \\
\hline & Thicket 2 & & $\begin{array}{l}\text { Trees from the higher height class are } \\
\text { also present }\end{array}$ \\
\hline \multirow[t]{3}{*}{ Pole wood } & Pole wood 1 & \multirow{3}{*}{$10<\mathrm{h}<20$} & No trees from the higher height class \\
\hline & Pole wood 2 & & $\begin{array}{l}\text { Trees from the higher height class are } \\
\text { also present }\end{array}$ \\
\hline & Pole wood 3 & & Tending to two layer forest \\
\hline Adult forest & Adult forest & $18<\mathrm{h}<25$ & - \\
\hline Mature forest & Mature forest & $\mathrm{h}>25$ & - \\
\hline \multirow{2}{*}{$\begin{array}{l}\text { Multilayer } \\
\text { forest }\end{array}$} & Two-layered forest & - & Two clear layers can be identified \\
\hline & Multilayer forest & - & - \\
\hline
\end{tabular}

respond to the position of each tree.

The distinction between forested and nonforested areas (land cover map) was made by using an algorithm that automatically detects the openings of the forest cover through classification of the values obtained from the Laser Penetration Index (LPI - Barilotti et al. 2006). Classified pixels were then grouped in homogenous cover classes according to the following definitions:

- forest: land with tree crown cover (or equivalent stocking level) of more than $20 \%$ and area larger than 0.2 ha;

- shrubland: vegetation lower than 3 meters above ground;

- bare soil.

Coniferous/broadleaves map was obtained through an automated extraction of individual trees using a "Top Hat" algorithm followed by an automatic crown delineation (Barilotti et al. 2007). Points which depended on the same crown were identified through a cluster analysis and each crown was delineated using circular polygons whose center and radius were calculated according to the planimetric coordinates of points belonging to each cluster. Crown depth was calculated as the difference between maximum and minimum height of point belonging to the cluster and total tree height was determined by subtracting DTM from crown vertex. Following previous work by Barilotti et al. (2009), trees were then classified as broadleaves or conifers according to parabolic surfaces approximating crown points' distribution and coniferous and broadleaf trees were grouped in homogeneous polygons through a region growing algorithm (Haralick \& Shapiro 1992). Finally, areas with a presence of conifers or broadleaves higher than $65 \%$ were treated as coniferous or broadleaf stands, respectively. Otherwise, they were treated as mixed forests.
The forest structure map was obtained through a classification of tree heights within forest areas following the criteria reported in Tab. 2. Also in this case, areas with an homogeneous distribution of tree height classes were delimited through a region growing algorithm (Haralick \& Shapiro 1992). Main structural categories adopted in Tab. 2 followed the definitions used for forest management plans in the Region Friuli Venezia Giulia (regeneration phase, ticket, pole wood, adult forest, mature forest, multilayer forest - Piussi 1994, Del Favero et al. 2000). However, as most of the forest stands in the area are managed according to shelterwood system on small areas, we also used a more detailed structural type classification (Tab. 2 ) in order to better underline the different forest development stages (i.e., stand after regeneration cut or stand after final cut). In order to better distinguish shrublands from regeneration phase, a manual check using the available digital areal photos for the area and considering elevation was performed.

\section{Ground data elaborations}

Starting from measured diameters and heights, specific height curves [i.e., $\mathrm{H}=$ $f(\mathrm{DBH})]$ were derived and Lorey's mean height (LMH) was calculated for each plot. LMH weights the contribution of trees to the stand height by their basal area, and is more stable than an unweighted mean height, because it is less affected by mortality and harvesting of the smaller trees. Biomass and volume were calculated according the regional allometric relationships proposed by Del Favero et al. (2000) and Anfodillo et al. (2006) and already applied by De Simon et al. (2012) in the Region.

Estimated Braun-Blanquet scale values were transformed in a 1-9 ordinal transform scale as proposed by Westhoff \& Van Der Maarel (1978) before statistical analysis of species cover. The characterization of the vegetation was performed through a Canonical (Constrained) Correspondence Analysis (CCA - Ter Braak 1986, Legendre \& Legendre 1998, Borcard et al. 2011) based on the relevés matrix and environmental factors matrix (i.e., LiDAR structures), and a cluster analysis, applied to plot vegetation relevés, using a similarity ratio algorithm (Westhoff \& Van Der Maarel 1978) and Ward's aggregation method. The statistical significance of CCA was assessed by Monte Carlo permutation tests, using 500 permutations (Ter Braak 1988).

Biodiversity was quantified within each plot with specific indexes such as the floristic richness (number of species surveyed for sample area) and the Shannon diversity index (Shannon \& Weaver 1949).

The biological spectrum percentage values were transformed with an arcsin angular transformation before the application of the analysis of variance (Knudsen \& Curtis 1947). Normality of the compared groups (i.e., biodiversity, biological spectrum group of each LiDAR structure category) was verified using the Shapiro's test for normality (Shapiro test, $p>0.05$ ), while the homogeneity of variances was tested using the Bartlett's test ( $p>0.05)$. Averages for each structural category were finally compared through an ANOVA $(\mathrm{p}<0.05)$ with post-hoc tests (Tukey test), for biodiversity indexes, and Kruskal-Wallis ANOVA by ranks $(\mathrm{p}<0.05)$ with non-parametric post-hoc tests (Nemenyi-Damico-Wolfe-Dunn test), for biological forms groups. All the statistical analyses were performed using R (C) R-Development Core Team).

\section{LiDAR data validation}

The validation of LiDAR structural data was performed following two methodologies depending on data type: for quality attributes (land cover map; coniferous/broadleaf map; forest structure map), Cohen's kappa coefficient (Cohen 1960) was used, while for quantitative attributes (i.e., height, stand density, biomass) linear and non-linear regressions or analysis of variance (ANOVA) in SigmaPlot 11 (Systat ${ }^{\circledR}$ Software Inc.) were used.

Kappa coefficient can be used as a measure of agreement between model predictions and reality (Congalton 1991) or to determine if the values contained in an error matrix represent a result significantly better than random (Jensen 1996). In particular, contingency tables based on ground points were built: columns were reference data, rows were LiDAR classifications. In the case of land cover map validation, a contingency table based on all $100 \times 100 \mathrm{~m}$ grid points within the study area was built (1694 points) and real land cover was assessed through visual photo-interpretation at each sampling 
point using a 2007 digital aerial photos available for the study area. Coniferous/ broadleaf map and forest structure map were both validated using the 37 ground points for which dendrometric measurements were available.

Kappa coefficient $(\kappa)$ was computed according to the following equation (eqn. 1):

$$
\kappa=\frac{\operatorname{Pr}(a)-\operatorname{Pr}(e)}{1-\operatorname{Pr}(e)}
$$

where $\operatorname{Pr}(a)$ is the relative observed agreement among raters, and $\operatorname{Pr}(e)$ is the hypothetical probability of chance agreement, using the observed data to calculate the probabilities of each observer randomly saying each category. If the raters are in complete agreement then $\kappa=1$. If there is no agreement among the raters other than what would be expected by chance - as defined by $\operatorname{Pr}(e)-, \kappa$ $=0$.

\section{Results}

Land cover and coniferous/broadleaf map validation

The contingency table used to validate the land cover map is reported in Tab. 3. Based on criteria established by Landis \& Koch (1977), a strong agreement between the map and ground data was found: the accuracy of the map was $97 \%$ (1638 were rightly classified) and K-Cohen was equal to $94 \%$. Instead, a moderate agreement between coniferous/broadleaf map and ground data (data not shown) was found: map accuracy was $73 \%$ and $\mathrm{K}$-Cohen was equal to $60 \%$. The comparison between map and ground data did not improve if only trees larger than 12.5 $\mathrm{cm}$ were considered in the analysis (accuracy $=70 \%$, K-Cohen $=58 \%$ ).

\section{Forest structure map validation}

The analysis of the forest structure map derived from LiDAR data revealed a prevalence of even-age stands $(66 \%)$ in comparison to the multilayered and uneven-aged forests (20\% - Fig. 2, Tab. 2). In particular, the even-age stands, whether adult or mature, were overwhelming (33\%). However, if we consider the structural categories separately, the most represented in terms of hectares was the pole wood $(21 \%)$, while the regeneration phase was less present $(<1 \%)$. The lack of this last category is partly due to the difficulties in separating it from scrublands or from two-layered stands because of the particular forest management applied in the study area (shelterwood system on small areas). In such a system, the seed cut often results in two-layered structures with plants of the previous cycle in the upper layer and a dense regeneration in the understory. Although the category "two-layered forest" is poorly represented $(2 \%)$, this situation is
Tab. 3 - Contingency table and calculation of Kappa Cohen's coefficient for the validation of cover use map.

\begin{tabular}{lcccc}
\hline \multirow{2}{*}{ LIDAR map } & \multicolumn{4}{c}{ Field plots } \\
\cline { 2 - 5 } & bare soil & forest & shrubs & Samples \\
\hline bare soil & 603 & 5 & 23 & 631 \\
forest & 2 & 917 & 9 & 928 \\
shrubs & 12 & 5 & 118 & 135 \\
Samples & 617 & 927 & 150 & 1694 \\
\hline Sample size & 1694 & & & \\
Correctly classified & 1638 & & & \\
Accuracy & $97 \%$ & & & \\
P chance & $47 \%$ & & & \\
K-Cohen & $94 \%$ & & & \\
\hline
\end{tabular}

better highlighted if the structural types are considered separately instead of aggregating them. In fact, there is a significant presence of "pole wood 2" and "pole wood 3" types which are stands with the presence of plants of the old cycle even if the regeneration is quite widespread (Tab. 4). In order to get an easier comparison between LiDAR and ground data, it was decided to show most of the results at category level and fall to type only in few cases for a more detailed analysis.

Mean stand characteristics for each forest category, as derived from ground plots, are reported in Tab. 5. Comparing LiDAR forest structure map with ground surveys, a highly significant correlation between average height derived from LiDAR and Lorey's mean height was detected $\left(\mathrm{H}_{\mathrm{LIDAR}}=0.86 \mathrm{x}\right.$ $\mathrm{H}_{\text {Lorey }}-0.30 ; \mathrm{R}^{2}=0.64 ; \mathrm{P}<0.001$; trees with $\mathrm{DBH}>4.5 \mathrm{~cm}-$ Fig. 3). The underestimation of mean height using LiDAR is probably due to difficulties in detecting small diameter trees because of the low posting density. This density was probably enough in the case of adult or mature forests, but it was insufficient for thicket or pole wood where stem density could be more than 2000 trees

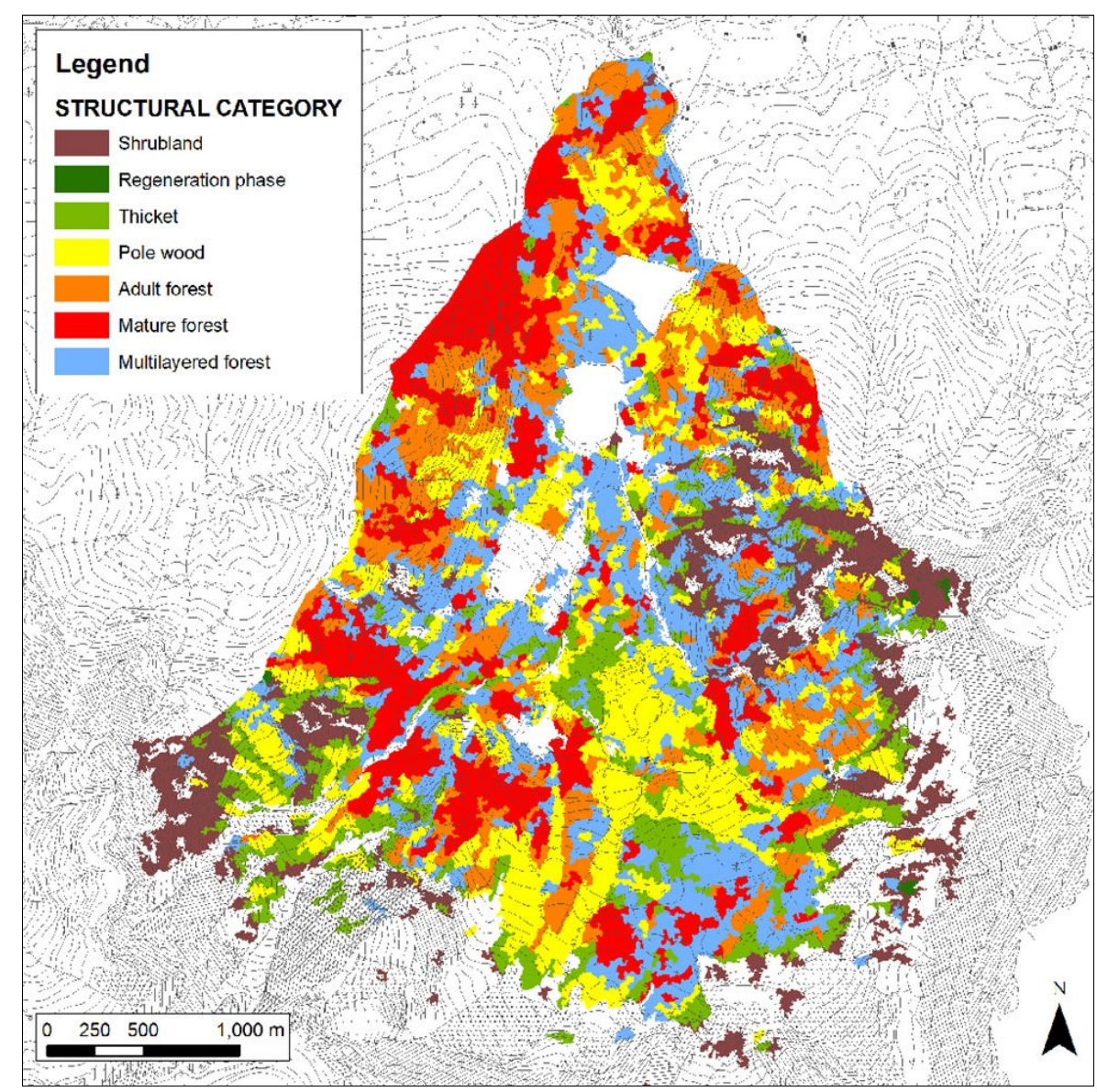

Fig. 2 - Forest structure map. 
$\mathrm{ha}^{-1}$. In fact, if only trees with a DBH greater than $12.5 \mathrm{~cm}$ were considered, there was a strong agreement between LiDAR-estimated mean height and Lorey's mean height $\left(\mathrm{H}_{\mathrm{LiDAR}}\right.$ $=\mathrm{H}_{\text {Lorey }}-5.35$; intercepts not significantly different from zero; $\mathrm{R}^{2}=0.57 ; \mathrm{P}<0.001$ ).

The correlation between stem density estimated from LiDAR data and measured in the field was not significant when considering all categories (data not shown), whereas correlation considering adult and mature forest (DBH greater than $12.5 \mathrm{~cm}$ ) was significant $\left(\mathrm{D}_{\text {LiDAR }}=0.31 \times \mathrm{D}_{\text {plot }}+174 ; \mathrm{R}^{2}=0.71\right.$; $\mathrm{P}<0.01)$ although the LiDAR tended to underestimate the density.

The overall accuracy of the LiDAR forest structure map was $68 \%$ (25 of 32 ground points matched with those reported from the map). Thus, a moderate agreement was detected between the map and ground data (Kappa Cohen coefficient was equal to $58 \%$ - Landis \& Koch 1977). The major discrepancies were found especially for pole woods and multilayered stands, while the greatest agreement was found for adult and mature forests. Again, this can be attributed to the high tree density in the young phases (pole wood and thicket) and to the low LiDAR posting density.

If only the 25 points for which there was a perfect correspondence between the ground and LiDAR are considered (Fig. 4), it is possible to describe the vertical distribution of the trees within the canopy. In the thicket, most of the trees were below $10 \mathrm{~m}$ and no significant differences were detected between LiDAR and ground plot data for any height class $(\mathrm{P}>0.05)$. In the pole wood, most of the trees were between $10-20 \mathrm{~m}$ and a significant difference between LiDAR and ground survey was detected only for the class $10-20 \mathrm{~m}$ class $(\mathrm{P}<0.001)$. The adult forest was mainly composed of trees higher than $20 \mathrm{~m}$ and no differences were detected between LiDAR and ground survey for any height class $(P>0.05)$. In the case of mature forest, a significant difference was detected for the class $10-20 \mathrm{~m}$ and for the class $>25$ $\mathrm{m}(\mathrm{P}<0.001)$. In the multilayered stands there was not a dominant height class and no differences were detected between LiDAR and ground survey.

If the points for which there was not a match between map and ground data are considered (data not shown), the two most common differences between LiDAR and ground survey results were respectively: (1) multilayer forest instead of pole wood; (2) mature forest instead of multilayer forest. In the first case, the classification error was probably related to the impossibility for LiDAR to detect correctly the dominant plants. In the second case, the discrepancy may be related to plot size that did not allow us to detect trees of the old cycle. Moreover, this error may also be related to the fact that
Tab. 4 - Area covered by each forest category and forest type identified from LiDAR data.

\begin{tabular}{llccc}
\hline Category & Type & $\begin{array}{c}\text { Area } \\
\text { (ha) }\end{array}$ & $\begin{array}{c}\text { Category } \\
\text { (\% of total area) }\end{array}$ & $\begin{array}{c}\text { Type } \\
\text { (\% total area) }\end{array}$ \\
\hline Scrubland & Scrubland & 127.9 & 12 & 12 \\
\hline Regeneration & Regeneration 1 & 0 & 0 & 0.2 \\
phase & Regeneration 2 & 1.8 & 0.2 & 11 \\
\hline Thicket & Thicket 1 & 45.4 & 4 & \\
& Thicket 2 & 74.7 & 7 & 21 \\
\hline Pole wood & Pole wood 1 & 60.1 & 6 & 16 \\
& Pole wood 2 & 152.5 & 14 & 17 \\
\hline Adult forest & Pole wood 3 & 10.6 & 1 & 2 \\
\hline Mature forest & Malult forest & 168.9 & 16 & 20 \\
\hline Multilayer forest forest & Two-layered forest & 22.8 & 17 & - \\
& Multilayer forest & 207.3 & 2 & \\
\hline Total & - & 1052.3 & - & \\
\hline
\end{tabular}

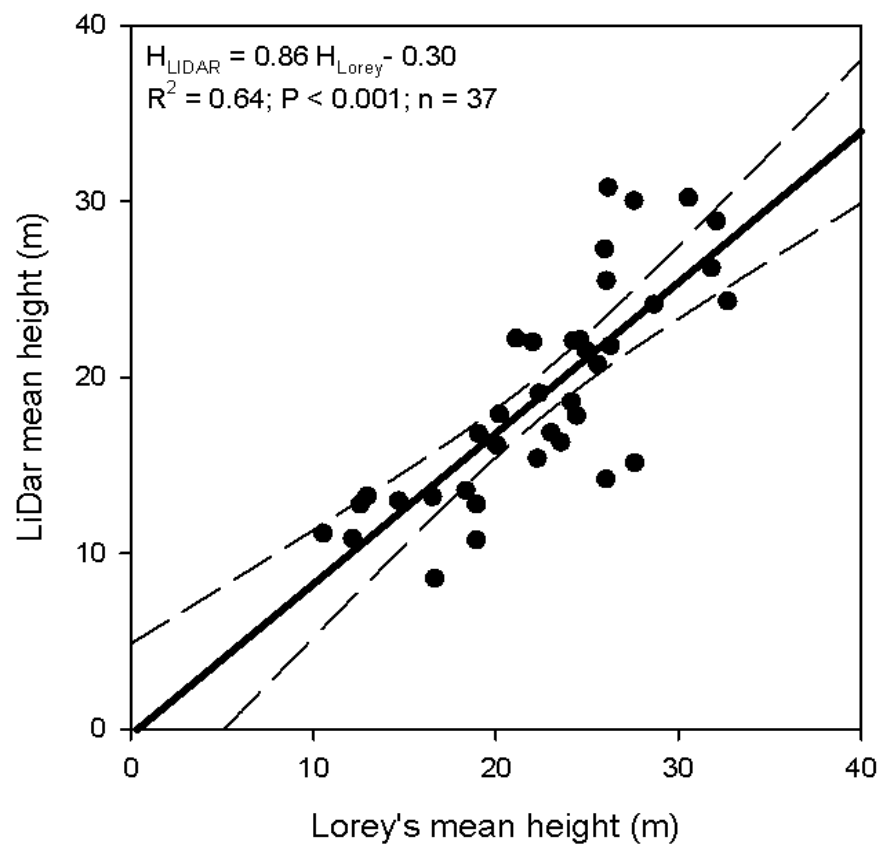

Fig. 3 - LiDAR-estimated mean height $v s$. Lorey's mean height (all trees with DBH greater than $4.5 \mathrm{~cm}$ ). The continuous line indicates the regression line. The intercept is not significantly different from zero $(\mathrm{P}=0.90)$. The dashed lines indicate $95 \%$ confidence intervals.

Tab. 5 - Characteristics of the main forest categories derived from ground plots (mean \pm standard error). $\left(\mathrm{H}_{\text {lorey }}\right)$ : Lorey's mean height; $\left(\mathrm{H}_{\mathrm{d}}\right)$ : dominant height (mean height of the dominant trees in an even-aged stands); (S): top height (mean height of the trees with the largest DBH in a stand uneven-aged stands).

\begin{tabular}{|c|c|c|c|c|c|c|}
\hline \multirow[t]{2}{*}{ Category } & \multicolumn{2}{|c|}{$\begin{array}{l}\text { Stand density } \\
\left(\mathrm{n} \mathrm{ha}^{-1}\right)\end{array}$} & \multicolumn{2}{|c|}{$\begin{array}{c}\text { Basal area } \\
\left(\mathrm{m}^{2} \mathrm{ha}^{-1}\right)\end{array}$} & \multirow{2}{*}{$\begin{array}{c}\mathbf{H}_{\text {Lorey }} \\
(\mathbf{m})\end{array}$} & \multirow{2}{*}{$\begin{array}{c}\mathbf{H}_{\mathrm{d}} \text { or } \mathrm{S} \\
\text { (m) }\end{array}$} \\
\hline & total & $\mathrm{d}>12.5 \mathrm{~cm}$ & total & $\mathrm{d}>12.5 \mathrm{~cm}$ & & \\
\hline Thicket & $2746 \pm 1761$ & $386 \pm 9$ & $23.0 \pm 4.4$ & $12.8 \pm 1.8$ & $15.5 \pm 3.4$ & $22.3 \pm 1.3$ \\
\hline Pole wood & $2246 \pm 286$ & $689 \pm 91$ & $36.4 \pm 3.7$ & $27.8 \pm 4.8$ & $18.4 \pm 1.3$ & $24.2 \pm 1.2$ \\
\hline Adult forest & $691 \pm 101$ & $656 \pm 93$ & $45.3 \pm 5.2$ & $45.1 \pm 5.2$ & $24.6 \pm 0.7$ & $28.5 \pm 0.8$ \\
\hline Mature forest & $537 \pm 88$ & $471 \pm 69$ & $63.9 \pm 5.1$ & $63.4 \pm 5.3$ & $30.7 \pm 1.1$ & $34.3 \pm 0.9$ \\
\hline $\begin{array}{l}\text { Multilayer } \\
\text { forest }\end{array}$ & $1014 \pm 169$ & $569 \pm 86$ & $43.0 \pm 5.1$ & $40.4 \pm 4.9$ & $25.1 \pm 1.1$ & $34.2 \pm 1.2$ \\
\hline
\end{tabular}



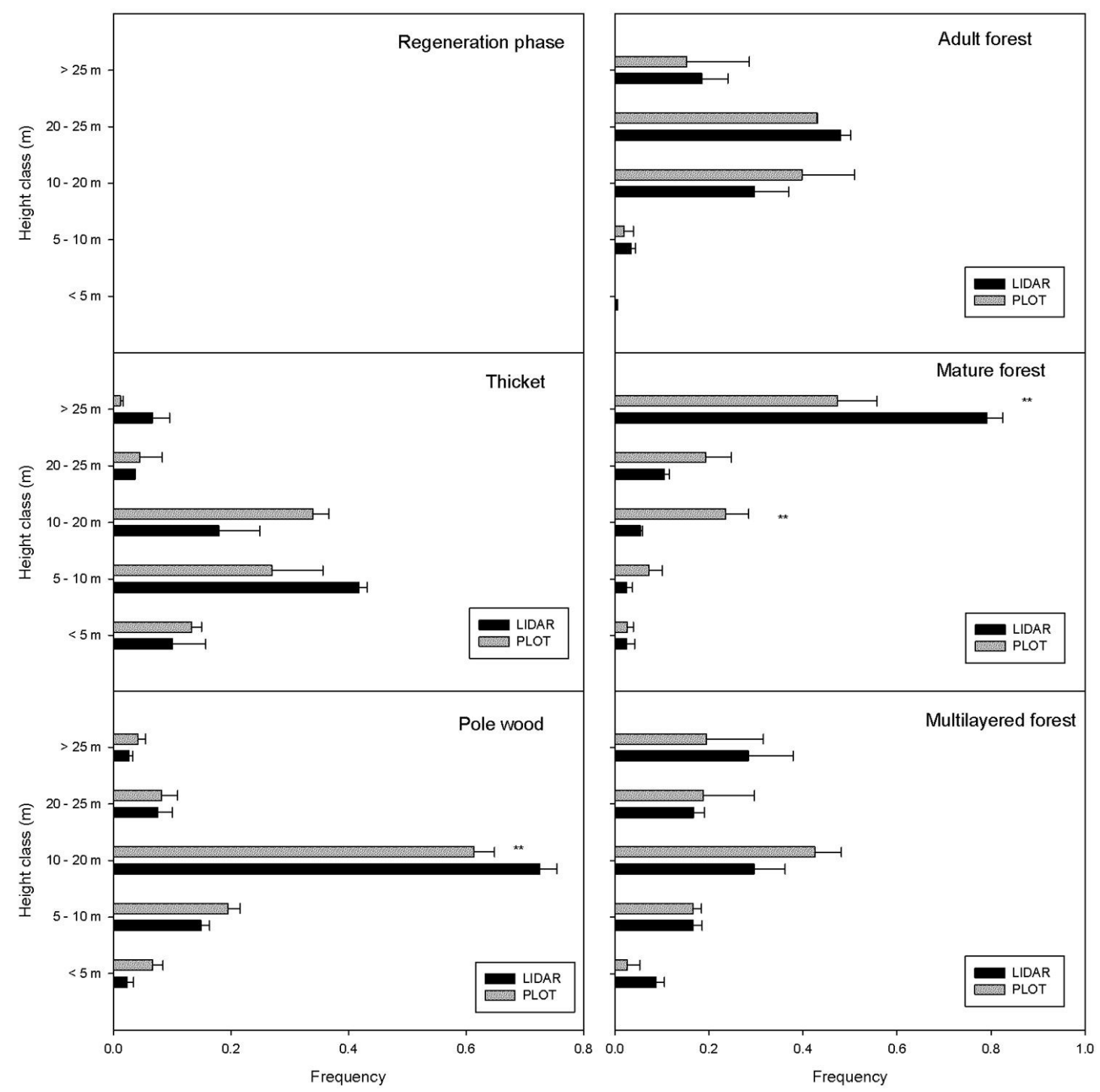

Fig. 4 - Mean stem distribution in height classes for the different structural categories. The twenty-five points for which there was a perfect correspondence between the ground and LiDAR data are reported. The category "multilayer forest" includes also "two-layer stands". The ho rizontal bars indicate the standard error of the mean. Asterisks indicate a significant difference $(\mathrm{P}<0.001)$ between LiDAR and ground survey for a specific height class.
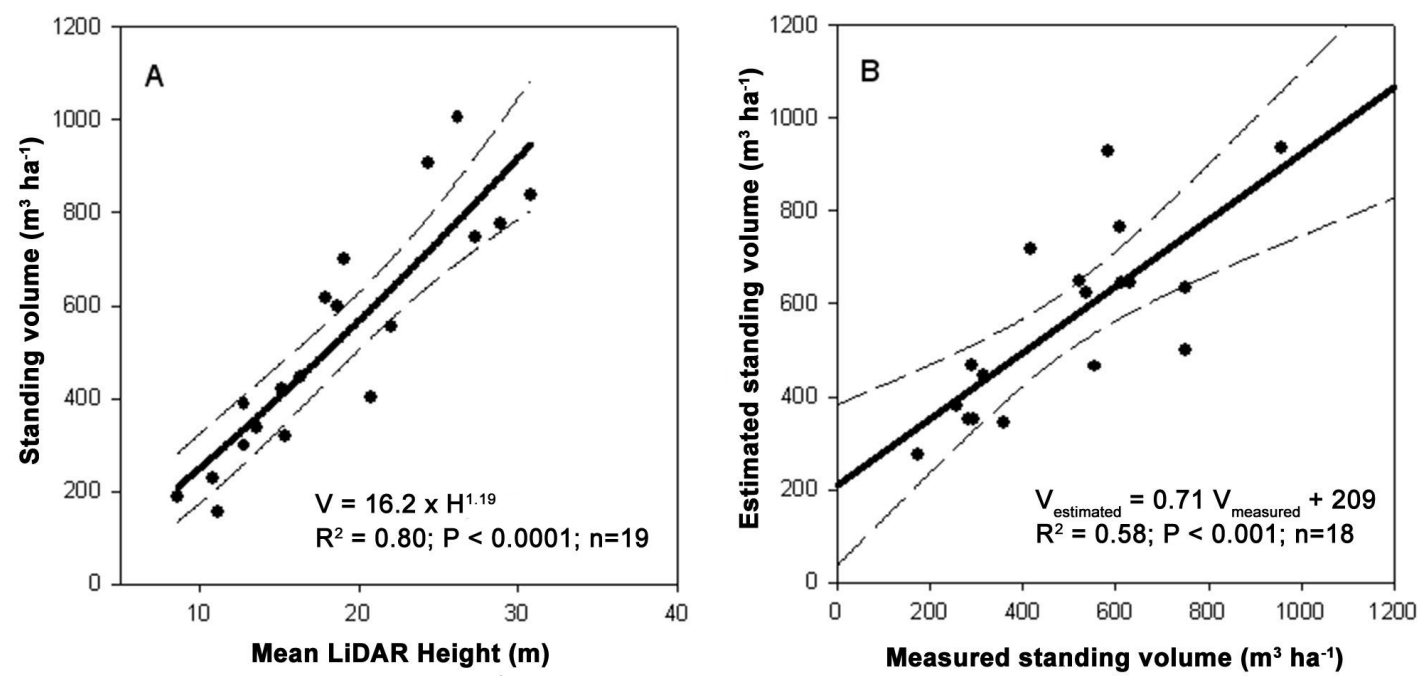

Fig. 5 - Model calibration to estimate total aboveground standing volume (A) and its validation (B). For calibration 19 plots were randomly selected and standing volume was plotted against LiDARestimated mean height. For validation, the remaining plots were used. The dashed lines represent the $95 \%$ confidence intervals. 

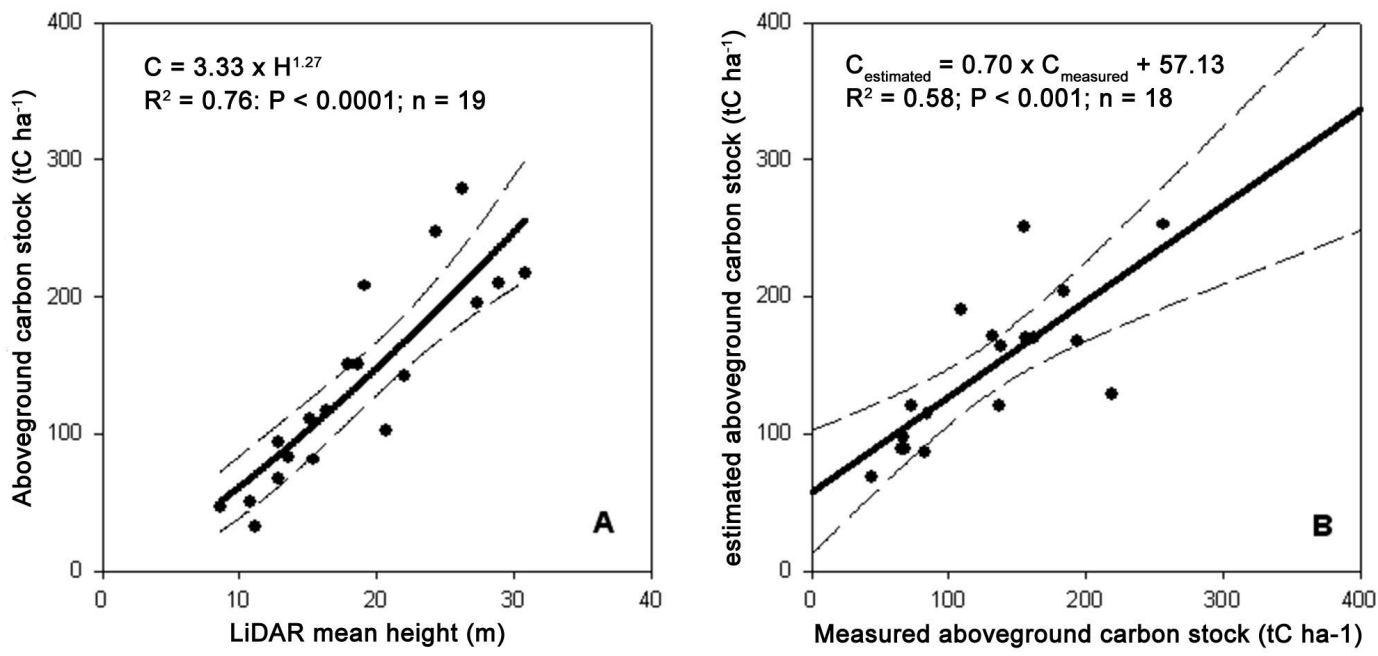

Fig. 6 - Model calibration to estimate total aboveground carbon stock (A) and its validation (B). For calibration 19 plots were randomly selected and aboveground carbon stock was plotted against LiDAR-estimated mean height. For validation, the remaining plots were used. The dashed lines represent the $95 \%$ confidence intervals.

LiDAR data refers to 2006-2009, while the measurements were carried out in 2010-2011 and then the plants of the old cycle may have already been cut in the meantime.

Volume and aboveground carbon stocks On average, total standing volume derived from ground plots was equal to $509 \pm 37 \mathrm{~m}^{3}$ ha $^{-1}$, while standing volume for trees with DBH greater than $12.5 \mathrm{~cm}$ was equal to $469 \pm 42 \mathrm{~m}^{3} \mathrm{ha}^{-1}$. Mature forest had the highest total standing volume $\left(805 \pm 83 \mathrm{~m}^{3}\right.$ $\left.\mathrm{ha}^{-1}\right)$ followed by adult and multilayer forest $\left(589 \pm 63\right.$ and $521 \pm 75 \mathrm{~m}^{3} \mathrm{ha}^{-1}$, respectively). Thicket had the lowest standing volume $\left(201 \pm 27 \mathrm{~m}^{3} \mathrm{ha}^{-1}\right)$ followed by pole wood

\section{$\left(419 \pm 49 \mathrm{~m}^{3} \mathrm{ha}^{-1}\right)$.}

A power function was fitted on standing volume data using LiDAR-estimated mean height as independent variable. For model calibration, we randomly selected 19 ground plots. Total standing volume was significantly related to the average height derived from $\operatorname{LiDAR}$ data $\left(\mathrm{V}=16.2 \cdot \mathrm{H}^{1.19} ; \mathrm{R}^{2}=0.80\right.$;
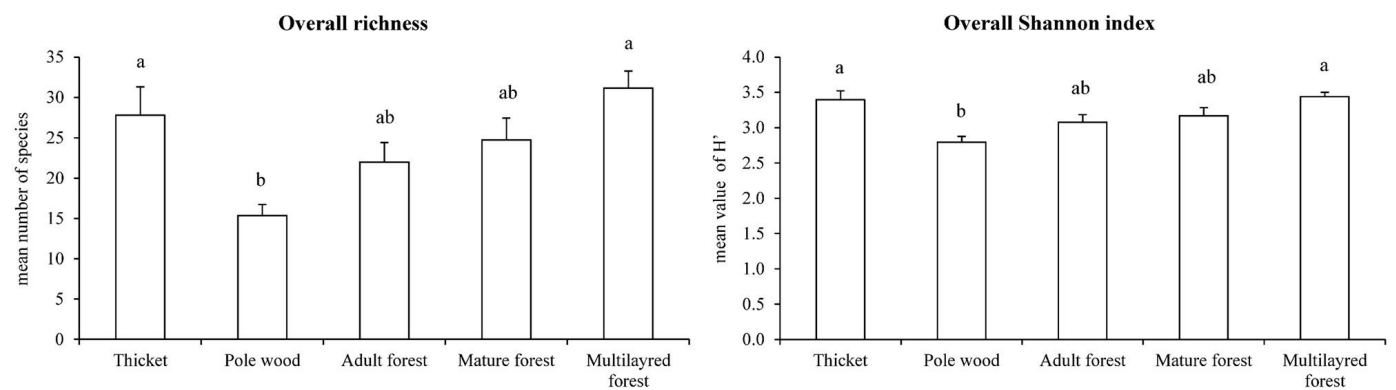

Fig. 7 - Overall biodiversity indexes and LiDAR forest structural categories. Different letter indicate statistical significance $(\mathrm{P}<0.05)$.
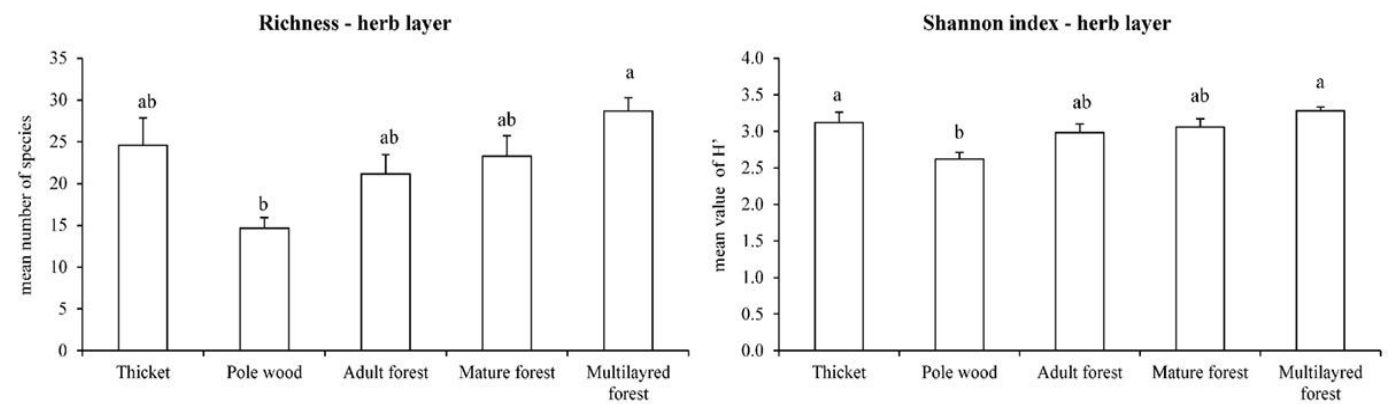

Fig. 8 - Forest layers biodiversity indexes and LiDAR forest structural categories. Different letter indicate statistical significance $(\mathrm{P}<0.05)$.
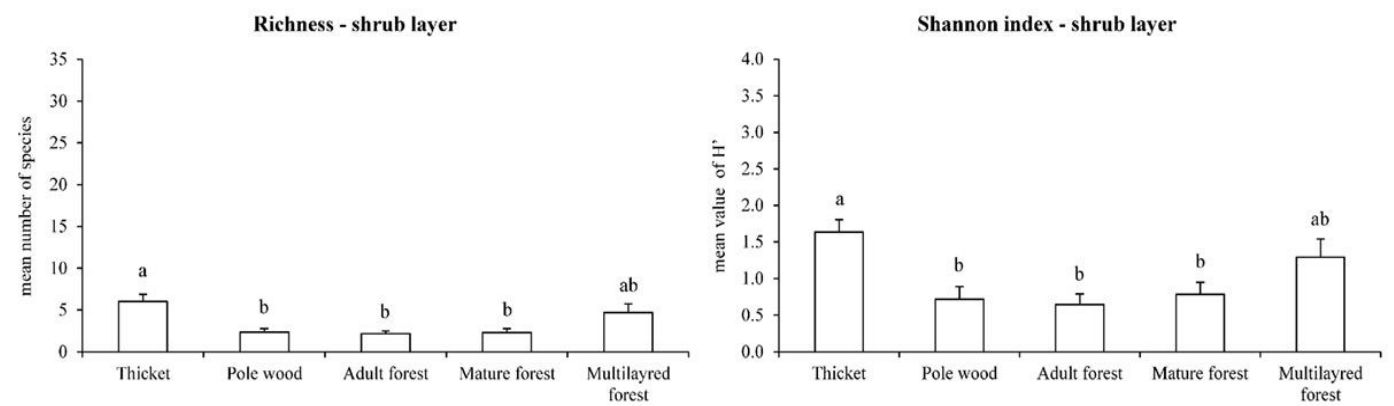
Tab. 6 - Frequencies of life forms in each LiDAR structure category. (Ch): Chamaephytes; (G): Geophytes; (H): Hemicryptophytes; (P): Phanerophytes; (NP): Nano- Phanerophytes; (T): Therophytes. Mean values and standard deviation $( \pm$ SD) are showed. Different letters indicate a significant difference $(\mathrm{P}<0.05)$.

\begin{tabular}{lccccc}
\hline \multicolumn{1}{c}{ Category } & Ch & G & H & P (inc. NP) & T \\
\hline Thicket & $0.08 \pm 0.02$ & $0.28 \pm 0.10 \mathrm{ab}$ & $0.38 \pm 0.09$ & $0.26 \pm 0.05$ & - \\
Pole wood & $0.04 \pm 0.05$ & $0.41 \pm 0.11 \mathrm{a}$ & $0.33 \pm 0.09$ & $0.22 \pm 0.07$ & - \\
Adult forest & $0.08 \pm 0.06$ & $0.35 \pm 0.05 \mathrm{a}$ & $0.36 \pm 0.11$ & $0.21 \pm 0.06$ & $0.00 \pm 0.01$ \\
Mature forest & $0.07 \pm 0.06$ & $0.30 \pm 0.09 \mathrm{ab}$ & $0.44 \pm 0.10$ & $0.17 \pm 0.04$ & $0.01 \pm 0.02$ \\
Multilayred forest & $0.10 \pm 0.06$ & $0.23 \pm 0.06 \mathrm{~b}$ & $0.47 \pm 0.13$ & $0.19 \pm 0.07$ & $0.01 \pm 0.01$ \\
\hline
\end{tabular}

$\mathrm{P}<0.0001$ - Fig. 5a) explaining $80 \%$ of the volume variability. Model validation was performed using the remaining plots and it was also significant $\left(\mathrm{R}^{2}=0.58 ; \mathrm{P}<0.001\right.$ Fig. 5b). Similar to the volume, LiDAR-estimated mean height was a good estimator of the aboveground carbon stock $(\mathrm{C}=3.33$ $\mathrm{H}^{1.27} ; \mathrm{R}^{2}=0.76 ; \mathrm{P}<0.0001$ - Fig. 6a and Fig. $6 \mathrm{~b})$. Overall, the carbon stock in the study area was $128.631 \mathrm{MgC}$, corresponding to $139 \mathrm{MgC} \mathrm{ha}{ }^{-1}$. Most of the stock was located in adult and mature forests (27808 and $39116 \mathrm{MgC}$, respectively).

\section{Vegetation analysis}

\section{Biodiversity and life-form plant functional type}

In total, 144 taxa (including species, subspecies and variety) belonging to 49 families were identified, with an average of 24 taxa for each plot. A significant difference in floristic diversity indexes (species richness - R; Shannon index - H') was found between pole $\operatorname{wood}\left(\mathrm{R}=15\right.$ and $\mathrm{H}^{\prime}=2.8 ; \mathrm{P}<0.01$ - Fig. 7) and multilayer forest $\left(\mathrm{R}=31\right.$ and $\left.\mathrm{H}^{\prime}=3.4\right)$ or thicket $\left(\mathrm{R}=28\right.$ and $\left.\mathrm{H}^{\prime}=3.4\right)$, where both the indexes reached their maximum values. On the other hand, mature $(\mathrm{R}=25$ and $\left.H^{\prime}=3.2\right)$ and adult forests $\left(\mathrm{R}=22\right.$ and $\left.\mathrm{H}^{\prime}=3.1\right)$ did not significantly differ from the other LiDAR classes ( $\mathrm{P}>0.05$ - Fig. 7). Plant biodiversity was mainly related to the understory richness (Fig. 8) and in particular to the herb layer contribution which, on the average, showed 22 taxa and an H' of 3.0. Within the herb layer, multilayer forest had the highest values for both the indexes $(\mathrm{R}=29$, $\mathrm{H}^{\prime}=3.3$ ), while pole wood showed significant lower values $\left(\mathrm{R}=15, \mathrm{H}^{\prime}=2.6\right)$. An increase in herbaceous species number from young (pole wood) to mature stages (mature and adult forest) was also found. For shrub layer diversity, significant differences between thicket and pole wood, mature and adult forest were found (Fig. 8).

As expected, all forest stands were quite homogeneous in terms of tree species composition. However, the highest tree species number was found in thicket $(\mathrm{R}=3.0)$ and multilayer forest $(\mathrm{R}=2.2)$ while pole wood, adult and mature forest showed the same values $(\mathrm{R}=1.8)$.

In terms of biological spectrum, the hemi- cryptophytes (H: 55\%), geophytes (G: $23 \%$ ) and phanerophytes (P: 15\%) were the most represented life forms groups while chamaephytes (Ch: $6 \%$ ) and therophytes (T: $1 \%$ ) showed the low values.

Comparing the structural categories, only geophytes group displayed significant differences (Tab. 6). Pole wood showed the highest values, while other structural categories (mature and old forest) had intermediate ones: hemicryptophytes and chamaephytes showed higher values in thicket/multilayer stands and pole wood, respectively; phanerophytes reached the maximum value in thicket stands while therophytes were minor.

\section{Characterization of vegetation by structure map stand}

CCA showed that $13 \%$ of the variability was explained by constrained variables $(\mathrm{P}<$ 0.01 - Tab. 7, Fig. 9). The remaining variability was due to the great heterogeneity of the site flora, as better described by cluster analysis. Despite of the low percentage of explained variability, it was possible to highlight two main trends. In particular, CCA1 axis identified a positive trend related to soil evolution from primitive limestone (i.e., thicket, pole wood), characterized by pioneer shrub species (e.g., Salix spp. and Corylus avellana), to medium evolved limestone soil, characterized by exigent species such as Lonicera caerulea, Dactylorhiza fuchsii and Listera cordata. CCA2 axis described a successional process of forest evolution which discriminates young and open forests (i.e., thicket and multilayer forest) and mature forests (i.e., pole wood, mature and adult stands). This trend was explained by a progressive change from pioneer and open forest species to high environmental stability and demanding mix forest species, such as Cardamine pentaphyllos, Actaea spicata and Stellaria nemorum.

Species scored permitted the discrimina- tion of a set of species strictly related with each LiDAR structure type:

- thicket was characterized by shrub species (e.g., Salix spp, Corylus avellana, Sorbus chamaemespilus);

- multilayer forest was mainly characterized by Orthilia secunda, Festuca altissima, Abies alba (tree level);

- pole wood was characterized by Sorbus aria, Veratrum lobelianum and Lonicera nigra;

- mature forest was characterized by Myosotis sylvatica, Galeopsisi speciosa and Carex sylvatica;

- adult forest was characterized by Neottia nidus-avis, Ranunculus auricomus (aggr.) and Anemone trifolia.

In terms of community characterization, all the stands were ascribable to the association Anemono-Fagetum (Marincek et al. 1989), which includes all the Illyrian mixed forests dominated by Fagus sylvatica and Picea abies, developed on limestone of mountain belt of the Querco-Fagetea class (Mucina 1997). The connection with the association Anemono-Fagetum was guaranteed by the constant presence of the Vaccinio-Piceetea class elements such as Picea abies, Vaccinium myrtillus, Vaccinium vitis-idaea subsp. vitis-idaea, and Carex alba. The connection with the higher syntaxonomical levels was guaranteed by a large nucleus of characteristics species, such as Luzula sylvatica subsp. sieberi and Polystichum lonchitis of the suballiance (Saxifrago-Fagenion), or Anemone trifolia and Fagus sylvatica for alliace (Aremonio-Fagion) and order (Fagetalia sylvaticae) characteristics.

The cluster analysis identified four main groups as variations of the trait plant community (Fig. 10). The identified types confirmed the general homogeneity in the analyzed stands and had not any syntaxonomical significance. However, the separation of these vegetation types represents a contribution for the interpretation of the relationship

Tab. 7 - CCA eigenvalues. Total inertia $=3.88$, Constrained $=0.50(13 \%, \mathrm{P}>0.01)$.

\begin{tabular}{lcccc}
\hline Parameters & CCA1 & CCA2 & CCA3 & CCA4 \\
\hline Eigenvalues for constrained axes & 0.17 & 0.15 & 0.12 & 0.07 \\
Proportion explained & 0.34 & 0.29 & 0.24 & 0.13 \\
Cumulative proportion & 0.34 & 0.63 & 0.87 & 1.00 \\
Species-environment correlations & 0.89 & 0.82 & 0.84 & 0.81 \\
\hline
\end{tabular}




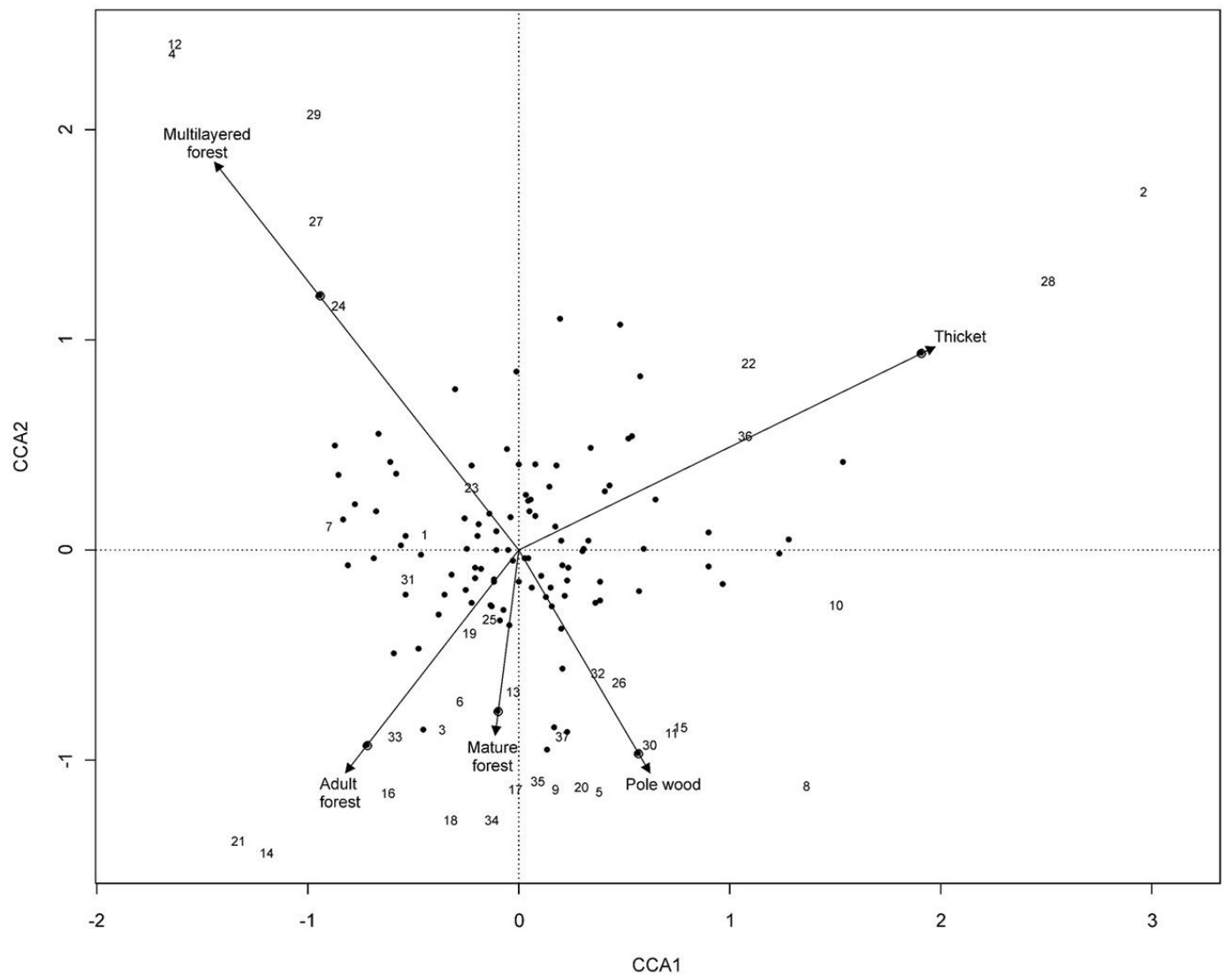

Fig. 9 - CCA biplot. The numbers indicate samples sites, and the solid circles indicate plant species.

between structure, dynamics and ecological value of the forest (French et al. 2008). Specifically, the cluster tree was split into two main groups: (1) mixed forests on primitive or medium evolved neutral substrates, corresponding mainly to pole wood and multilayer forest, which have low species rich- ness; (2) mixed forests evolved or primitives, rich in species, mainly owing to mature or old forest. Within the first group the following sub-groups were found: (a) pioneer stages with few association and sub alliance characteristic species, depleted floristic richness and ferns richness, and (b) acids evolved soil, with high frequency of blueberries (Vaccinium myrtillus, Vaccinium vitis-idaea subsp. vitis-idaea) and few of sub alliance and order characteristic species. Within the second group the following two clusters were identified: (c) heterogeneous stands with high floristic richness, many

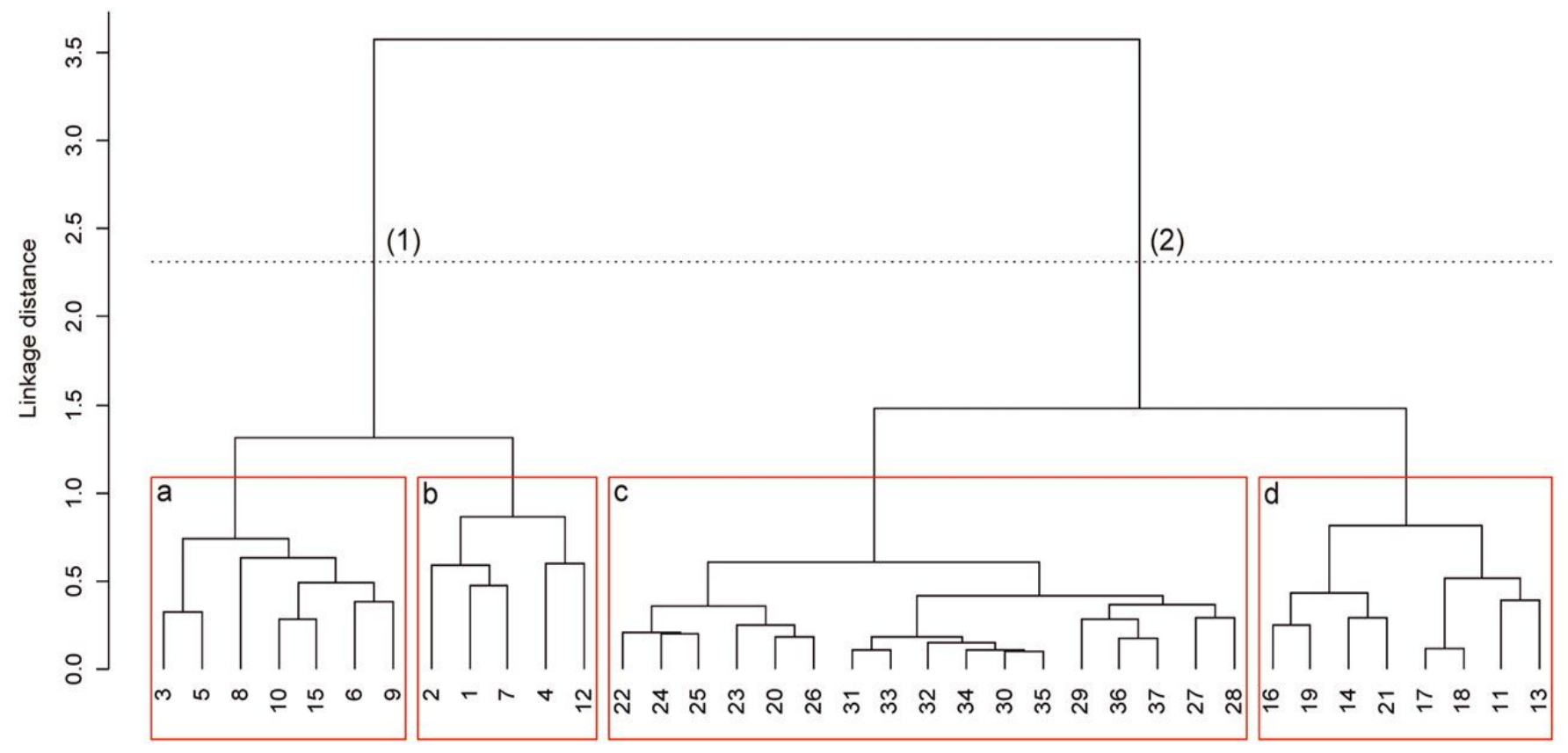

Fig. 10 - Cluster dendrogram of vegetation survey (similarity ratio, ward method). (1), (2) = first cut; a, b, c, d = second cut. The numbers in dicate sample sites. 
Tab. 8 - Cluster groups sharing into LiDAR structural categories. (1), (2): first cut of cluster dendrogram; (a), (b), (c), (d): second cut of cluster dendrogram.

\begin{tabular}{lccccccc}
\hline \multirow{2}{*}{ Groups } & \multicolumn{9}{c}{$\mathbf{( 1 )}$} & & & $\mathbf{( 2 )}$ & \multirow{2}{*}{ total } \\
\cline { 2 - 6 } & $\mathbf{a}$ & $\mathbf{b}$ & total 1 & $\mathbf{c}$ & $\mathbf{d}$ & total 2 & \\
\hline Regeneration phase & - & - & - & - & - & - & - \\
Thicket & 1 & 1 & 2 & 3 & - & 3 & 5 \\
Pole wood & 4 & - & 4 & 3 & 2 & 5 & 9 \\
Adult forest & 1 & - & 1 & 4 & 2 & 6 & 7 \\
Mature forest & - & 1 & 1 & 3 & 3 & 6 & 7 \\
Two-layred forest & 1 & 1 & 2 & - & - & - & 2 \\
Multilayred forest & - & 2 & 2 & 4 & 1 & 5 & 7 \\
Overall & 7 & 5 & 12 & 17 & 8 & 25 & 37 \\
\hline
\end{tabular}

characteristics species and participation of Larix decidua, and (d) mature stands with the highest number of characteristics species. Even though the structural classes did not perfectly match with each of the groups obtained from multivariate analysis (Tab. 8), a high correspondence between mature and adult forest stand and vegetation group 2 was pointed out.

\section{Discussion}

The most common methods to detect tree vertexes using LiDAR data are based on Canopy Height Models (CHM) created from the difference between a DTM and a Digital Surface Model (DSM - where cell value is the height of the highest laser point). In such cases, a stem is detected for every local maximum of the central cell of a $n$-sized moving window (Persson et al. 2002), where $n$ can also vary as a function of tree height (Popescu et al. 2002). The combined use of LiDAR and multi-spectral image data (Popescu \& Wynne 2004), as well as the local maximum of the correlation value between a moving-window template and the CHM above a threshold, has also been already tested (Pirotti 2010). However, all these methods are heavily dependent on the cell size of the raster models and on the moving window size, which tends to be a limiting factor when applied to complex stand conditions (Rowell et al. 2006). On the contrary, the method used in the present paper directly relies on the raw data (points) and has shown a good accuracy in extracting tree vertexes and detecting forest area (land cover map). In term of coniferous/broadleaf map, the main difficulty in distinguishing coniferous from mixed stands was probably due to the higher tree density, which decreases the number of points per crown available for the curve approximation, and/or the low LiDAR posting density $\left(2.8\right.$ points $\left.\mathrm{m}^{-2}\right)$, which did not allow us to proper characterize the understory vegetation (Barilotti et al. 2009) This low post density is typical of not dedicated flight (Clementel et al. 2012) and had also an influence in the accuracy of the structure map. A full-waveform (FW) survey would have probably been very supportive: post-processing a full-waveform could have doubled the number of returns (Reitberger et al. 2009), thus adding information for the cluster analysis and successive classification. It is also documented in literature that low posting density will lead to an underestimation of the tree height metrics, because it is likely that most of the tree vertexes will not be hit by a laser pulse (Nilsson 1996, Naesset 1997, Popescu et al. 2002).

Nilsson (1996), in a similar study in Sweden (4.0 ha area and 26 plots), explained $78 \%$ of the variability in forest stem volume using variables extracted from LIDAR. Previous studies in the Alps demonstrated the existing of correlation between stand volume and mean height derived from LiDAR data (Tonolli et al. 2011a, 2011b). In the present study, according to model validation, LiDAR-estimated mean height describes up to $58 \%$ of volume variability and $62 \%$ of carbon stocks variability in agreement with Naesset (2004). These results can be deemed as positive considering the different forest types, structures and categories considered in this study. However, they also underline the importance for an integration of ground and remotely sensed data to avoid bias in volume estimation, as model parameters are always site-specific.

In terms of plant species composition, all the stands were ascribable to the association Anemono-Fagetum (Marincek et al. 1989). The overall biological spectrum agreed with other literature spectra of local mixed deciduous forest (Poldini \& Nardini 1993, Del Favero et al. 1998) and the comparison of each biological spectrum with structural categories (Tab. 6) highlighted an overall homogeneity across all structural categories. However, while hemicryptophytes, phanerophytes and chamaephytes did not discriminate LiDAR structural categories, the distribution of geophytes seem to be a good guide group (Hermy et al. 1999). In particular, as shown in other forest types (Decocq et al. 2004, Gondard et al. 2006, Aubin et al. 2009), the abundance of geophytes group is strictly related to the shading degree of the forest stand (i.e., tree density, canopy cover). In our studied stands, this occurs especially in pole wood and adult forest, where the coverage of the canopy reaches its maximum.

The high richness of thicket and multilayered stands was due to the presence of a large number of shrub and herb species coming from open environments (i.e., pastures, alpine prairie and scree pioneer vegetation), as confirmed by the vegetation analysis. This trend may be explained by two different phenomena: (i) involvements of pioneer species in the early phases after forest disturbance (i.e., regeneration after harvest in thicket), in agreement with the intermediate-disturbance hypothesis (Grime 1973, Connell 1978, Battles et al. 2001); (ii) discontinuous structure of tree cover in multilayered stands, which allows the occurrence of grassland and light-demanding species (Vetaas 1997, Gondard et al. 2006, Bongers et al. 2009). On the other hand, the higher biodiversity, especially in the understory flora, was due to an increase in the complexity for this paraclimax communities, where rare species were more present (Lust et al. 1998, Battles et al. 2001). Vegetation type identification obtained through LiDAR structures, CCA and vegetation analysis (cluster) allowed us to detect a set of species that characterized each forest stand. These pools of characteristic species also explained the existence of different ecological features amongst LiDAR structures (e.g., soil evolution, developmental phases of phytocoenoses).

The integration of floristic and phytosociological analyses allowed us to highlight a different contribution of LiDAR structural categories on vegetation characterization. In particular, the classical phytosociological analysis, exclusively focused on the vegetation resemblance, partially explained the variability observed among the LiDAR categories. Indeed, this emphasized the role of other ecological factors in influencing the species composition of each forest structural category that were not considered in this analysis, such as flora natural turnover and forest management.

\section{Conclusions}

The forest structure map derived from LiDAR data have proved to be a reliable tool for the characterization of forest stands in areas with an high natural interest if adequately supplemented by field analysis. In particular, the approach used in the present study was able to describe the study area from different points of view, all important for land management and planning. In fact, we were able to distinguish forest from nonforest areas, coniferous from broadleaf or mixed stands and to deeply characterize forest structure. The discrepancies we found between LiDAR forest structure map and ground points was probably due to the low LiDAR posting density (2.8 points $\left.\mathrm{m}^{-2}\right)$, 
which did not allow to proper characterize the understory vegetation, and relative small ground-plot size $\left(531 \mathrm{~m}^{2}\right)$ in comparison to the minimum LiDAR derived polygon area. LiDAR-estimated mean height was able to describe volume variability in the study area even though the integration of ground data and remotely sensed data is important to avoid bias in the estimation. In terms of vegetation characterization, the present study allowed to highlight the power of LiDAR structural maps to asses biodiversity and to characterize vegetation ecological stability. In particular, LiDAR derived mean heights allowed to characterized different structural phases which, in our case, were mainly related to different successional stages. This strong link between LiDAR structure map and biodiversity is mainly due to the fact that ecological conditions (i.e., light) are mainly influenced by vertical forest structure (i.e., discontinuous structure of tree cover in multilayered stands) and/or disturbance (i.e., regeneration after harvest in thicket). The approach proposed in this paper permitted to discriminate high natural values forest structures, where a careful management is more needed from a conservationist point of view. Moreover, some driver species were identified and related to each structural class.

In conclusion, this study highlights the potential of LiDAR-based approaches for the accurate classification and characterization of forest structures and succession phases in mixed coniferous forests. However, further research should be conducted across different forests types, characterized by different complexity and ecological diversity.

\section{Acknowledgements}

The work was funded by Direzione Centrale Risorse Rurali, Agroalimentari e Forestali - Servizio Gestione Forestale e Produzione Legnosa - Regione Friuli Venezia Giulia (Italy) - with a grant for innovation in the field of forest management (ALIFORMIDI project; 1.r. 26/2005 art. 16). LiDAR raw data elaboration was performed by e-Laser s.r.l. (http://www.e-laser.it). The authors would like to thank Stefania Gentili, Elisa Pizzolitto, Giacomo Blasone, Alessandro Merci, Andrea Tabacchi, for the help during field sampling.

\section{References}

Abramo E, Barilotti A, Sepic F (2007). Dalla dendrometria diametrica alla dendrometria ipsometrica: stima del volume degli alberi da rilievi laser-scanning. Forest@ 4: 373-385. - doi: 10.3832/efor0481-0040373

Anfodillo T, Pilli R, Salvatori I (2006). Indagine preliminare sullo stock di carbonio nelle foreste del Veneto. Regione Veneto.

Aubin I, Ouellette MH, Legendre P, Messier C, Bouchard A (2009). Comparison of two plant functional approaches to evaluate natural restora- tion along an old-field - deciduous forest chronosequence. Journal of Vegetation Science 20 (2): 185-198. - doi: 10.1111/j.1654-1103.2009. 05513.x

Barilotti A, Turco S, Alberti G (2006). LAI determination in forestry ecosystem by LiDAR data analysis. In: Proceeding of the "Workshop in 3D Remote Sensing in Forestry". Vienna (Austria= 14-15 February 2006.

Barilotti A, Sepic F, Abramo E, Crosilla C (2007). Improving the morphological analysis for tree extraction: a dynamic approach to lidar data. In: Proceedings of the "ISPRS Workshop on Laser Scanning 2007". Espoo (Finland) September 1214, 2007.

Barilotti A, Crosilla F, Sepic F (2009). Curvature analysis of lidar data for single tree species classification in alpine latitude forests. In: "Laser scanning 2009, IAPRS" (Bretar F, Pierrot-Deseilligny M, Vosselman G eds). Vol. XXXVIII, Part 3/W8 - 1-2 September 2009, Paris, France.

Bassler C, , Stadler J, Muller J, Forster B, Gottlein A, Brandl R (2011). LiDAR as a rapid tool to predict forest habitat types in Natura 2000 networks. Biodiversity and Conservation 20: 465481. - doi: 10.1007/s10531-010-9959-x

Battles JJ, Shlisky AJ, Barrett RH, Heald RC, Allen-Diaz BH (2001). The effects of forest management on plant species diversity in a Sierran conifer forest. Forest Ecology and Management 146: 211-222. - doi: 10.1016/S0378-1127(00) 00463-1

Beets PN, Brandon AM, Goulding CJ, Kimberley MO, Paul TSH, Searles N (2011). The inventory of carbon stock in New Zealand's post-1989 planted forest for reporting under the Kyoto protocol. Forest Ecology and Management 262: 1119-1130. - doi: 10.1016/j.foreco.2011.06.012 Bongers F, Poorter L, Hawthorne WD, Sheil D (2009). The intermediate disturbance hypothesis applies to tropical forests, but disturbance contributes little to tree diversity. Ecology letters 12 : 798-805. - doi: 10.1111/j.1461-0248.2009.013 29.x

Borcard D, Gillet F, Legendre P (2011). Numerical Ecology with R. Springer, New York, USA, pp. 306.

Braun-Blanquet J (1964). Pflanzensoziologie Grundzuge der Vegetationkunde. Springer, Wien, Austria and New York, USA.

Castillo-Nunez M, Sanchez-Azofeifa GA, Croitoru A, Rivard B, Calvo-Alvarado J, Dubayah RO (2011). Delineation of secondary succession mechanisms for tropical dry forests using LiDAR. Remote Sensing of Environment 115: 2217-2231. - doi: 10.1016/j.rse.2011.04.020

Clementel F, Colle G, Farruggia C, Floris A, Scrinzi G, Torresan C (2012). Estimating timber volume by means of "low cost" LiDAR data. Italian Journal of Remote Sensing 44: 125-140. doi: $10.5721 /$ ItJRS201244110

Cohen J (1960). A coefficient of agreement for nominal scales. Educational and Psychological Measurement 20: 37-46. - doi: 10.1177/00131 6446002000104

Collin A, Long B, Archambault P (2010). Salt- marsh characterization, zonation assessment and mapping through a dual-wavelength LiDAR. Remote Sensing of Environment 114: 520-530. doi: 10.1016/j.rse.2009.10.011

Congalton RG (1991). A review of assessing the accuracy of classifications of remotely sensed data. Remote Sensing of Environment 37: 35-46. - doi: 10.1016/0034-4257(91)90048-B

Connell JH (1978). Diversity in tropical rain forests and coral reefs. Science 199: 1302-1310. - doi: 10.1126/science.199.4335.1302

Coops NC, Hilker T, Wulder MA, St-Onge B, Newnham G, Siggins A, Trofymow JA (2007). Estimating canopy structure of Douglas-fir forest stands from discrete-return LiDAR. Trees-Structure and function 21: 295-310. - doi: 10.1007/ s00468-006-0119-6

Corona P, Kohl M, Marchetti M (2003). Advances in forest inventory for sustainable forest management and biodiversity monitoring. Kluwer, Dordrecht, Germany.

Corona P, Chirici G, McRoberts RE, Winter S, Barbati A (2011). Contribution of large scale forest inventories to biodiversity assessment and monitoring. Forest Ecology and Management 262: 2061-2069. - doi: 10.1016/j.foreco.2011. 08.044

Corona P, Cartisano R, Salvati R, Chirici G, Floris A, Di Martino P, Marchetti M, Scrinzi G, Clementel F, Travaglini D, Torresan C (2012). Airbone laser scanning to support forest re source management under alpine, temperate and Mediterranean environments in Italy. European Journal of Remote Sensing 45: 27-37. - doi: 10.5721/EuJRS20124503

Decocq G, Aubert M, Dupont F, Alard D, Saguez $R$, et al (2004). Plant diversity in a managed temperate deciduous forest: understorey response to two silvicultural systems. Journal of Applied Ecology 41: 1065-1079. - doi: 10.1111/j.00218901.2004.00960.x

Del Favero R, Poldini L, Lasen C, Dreossi G, Vanone G (1998). La vegetazione forestale e la selvicoltura nella regione Friuli-Venezia Giulia. Regione Autonoma Friuli-Venezia Giulia, Direzione Regionale delle Foreste, Servizio della Selvicoltura.

Del Favero R, Bortoli PL, Staf SNC, Vanone G, Moro E (2000). Direttive per i piano di gestione delle proprietà forestali nella regione Friuli Venezia Giulia. Direzione Regionale delle Foreste, Regione Autonoma Friuli Venezia Giulia, pp. 256.

De Simon G, Alberti G, Delle Vedove G, Zerbi G, Peressotti A (2012). Influence of forest management on net ecosystem production across two different Italian chronosequences. European Journal of Forest Research 131 (5): 1297-1311. doi: 10.1007/s10342-012-0599-4

Drake JB, Dubayah RO, Clark DB, Knox RG, Blair JB, Hofton MA, Chazdon RL, Weishampel JF, Prince SD (2002). Estimation of tropical forest structural characteristics using large-footprint LiDAR. Remote Sensing of Environment 79: 305-319. - doi: 10.1016/S0034-4257(01) 00281-4 
Falkowski MJ, Evans JS, Martinuzzi S, Gessler PE, Hudak AT (2009). Characterizing forest succession with lidar data: An evaluation for the Inland Northwest, USA. Remote Sensing of Environment 113 (5): 946-956. - doi: 10.1016/j.rse. 2009.01.003

French LJ, Smith GF, Kelly DL, Mitchell FJG, O'Donoghue S, Iremonger SF, Mckee AM (2008). Ground flora communities in temperate oceanic plantation forests and the influence of silvicultural, geographic and edaphic factors. Forest Ecology and Management 255: 476-494. doi: $10.1016 /$ j.foreco.2007.09.014

Garcia M, Riano D, Chuvieco E, Danson FM (2010). Estimating biomass carbon stocks for a Mediterranean forest in central Spain using LiDAR height and intensity data. Remote Sensing of Environment 114: 816-830. - doi: 10.1016/j.rse.2009.11.021

Gillespie TW, Brock J, Wright CW (2004). Prospects for quantifying structure, floristic composition and species richness of tropical forests. International Journal of Remote Sensing 25: 707715. - doi: 10.1080/01431160310001598917

Gondard H, Romane F, Regina I, Leonardi S (2006). Forest management and plant species diversity in chestnut stands of three Mediterranean areas. In. "Forest diversity and management" (Hawksworth DL, Bull AT eds). Topics in Biodiversity and Conservation, Springer, The $\mathrm{Ne}$ therlands, pp. 69-82.

Grime JP (1973). Competitive exclusion in herbaceous vegetation. Nature 242: 344-347. - doi: $10.1038 / 242344 \mathrm{a} 0$

Haralick RM, Shapiro LG (1992). Computer and robot vision. Addison-Wesley, Longman Publishing Co. Inc., Boston, MA, USA.

Hermy M, Honnay O, Firbank L, Grashof-Bokdam C, Lawesson JE (1999). An ecological comparison between ancient and other forest plant species of Europe, and the implications for forest conservation. Biological Conservation 91: 9-22. - doi: 10.1016/S0006-3207(99)00045-2

IPCC (2001). Third assessment report. Climate change 2001. Cambridge University Press, Cambridge, UK

Jensen JR (1996). Introductory digital image processing: a remote sensing perspective. Prentice-Hall, Upper Saddle River, NJ, USA, pp. 318.

Kotchenova SY, Song XD, Shabanova NV, Potter CS, Knyazikhin Y, Myneni RB (2004). LiDAR remote sensing for modeling gross primary production of deciduous forests. Remote Sensing of Environment 92: 158-172. - doi: 10.1016/j.rse. 2004.05.010

Knudsen LF, Curtis JM (1947). The use of the angular transformation in biological assays. Journal of the American Statistical Association 42: 282296. - doi: 10.1080/01621459.1947.10501927

Landis JR, Koch GG (1977). The measurement of observer agreement for categorical data. Biometrics 33: 159-174. - doi: 10.2307/2529310

Lefsky MA, Cohen WB, Acker SA, Parker GG, Spies TA, Harding D (1999). Lidar remote sensing of the canopy structure and biophysical properties of Douglas-fir western hemlock forests. Remote Sensing of Environment 70: 339361. - doi: 10.1016/S0034-4257(99)00052-8 Legendre P, Legendre L (1998). Numerical ecology. Second english edition. Developments in Environmental Modelling 20, Elsevier Science BV, Amsterdam, The Netherlands, pp. 853.

Lim K, Treitz P, Wulder M, St-Onge B, Flood M (2003). LiDAR remote sensing of forest structure. Progress in Physical Geography 27: 88-106. - doi: 10.1191/0309133303pp360ra

Lust N, Muys B, Nachtergale L (1998). Increase of biodiversity in homogeneous Scots pine stands by an ecologically diversified management. Biodiversity and Conservation 7: 249-260. - doi: 10.1023/A:1008892620387

Maltamo M, Eerikainen K, Pitkanen J, Hyyppa J, Vehmas M (2004). Estimation of timber volume and stem density based on scanning laser altimetry and expected tree size distribution functions. Remote Sensing of Environment 90: 319330. - doi: 10.1016/j.rse.2004.01.006

Marincek L, Poldini L, Zupancic M (1989). Beitrag zur kenntniss der Gesellschaft Anemono Fagetum. Razprave 4, Razreda SAZU 30: 3-64.

Mucina L (1997). Conspectus of classes of European vegetation. Folia Geobotanica 32: 117172. - doi: 10.1007/BF02803738

Naesset E (1997). Determination of mean tree height of forest stands using airbone laser scanner data. Journal of Photogrammetry and Remote Sensing 52: 49-56. - doi: 10.1016/S0924-2716 (97)83000-6

Naesset E (2004). Practical large-scale forest stand inventory using small-footprint airborne scanning laser. Scandinavian Journal of Forest Research 19: 164-179. - doi: 10.1080/02827580 310019257

Naesset E, Gobakken T (2008). Estimation of above- and below-ground biomass across regions of the boreal forest zone using airborne laser. Remote Sensing of Environment 112: 3079-3090. doi: 10.1016/j.rse.2008.03.004

Nelson RF, Krabill W, Tonelli J (1988). Estimating forest biomass and volume using airborne laser data. Remote Sensing of Environment 24: 247-267. - doi: 10.1016/0034-4257(88)90028-4 Nilsson M (1996). Estimation of tree heights and stand volume using an airborne lidar system. Remote Sensing of Environment 56: 1-7. - doi: 10.1016/0034-4257(95)00224-3

Oberdorfer E (2001). Pflanzen-soziologische Exkursions-flora für Deutschland und angrenzende Gebiete. Ulmer, Stuttgart, Germany.

Pascual C, García-Abril A, García-Montero LG, Martín-Fernández S, Cohen WB (2008). Objectbased semi-automatic approach for forest structure characterization using lidar data in heterogeneous Pinus sylvestris stands. Forest Ecology and Management 255: 3677-3685. - doi: 10.1016/j.foreco.2008.02.055

Persson A, Holmgren J, Söderman U (2002). Detecting and measuring individual trees using an airborne laserscanner. Photogrammetric Engineering \& Remote Sensing 68(9): 925-932.

Pignatti S (1953). Introduzione allo studio fitoso- ciologico della pianura veneta orientale con particolare riguardo alla vegetazione litoranea. Arch. Bot. 29: 65-98.

Pignatti S (1982). Flora d'Italia. Edagricole, Bologna, Italy, vol. 2, pp. 474-475.

Pirotti F (2010). Assessing a template matching approach for tree height and position extraction from lidar-derived canopy height models of Pinus pinaster stands. Forests 1: 194-208. - doi: 10.3390/f1040194

Piussi P (1994). Selvicoltura generale. UTET, Torino, Italia, pp. 421.

Poldini L, Nardini S (1993). Boschi di forra, faggete e abieteti in Friuli (NE Italia). Studia Geobotanica 13: 215-298.

Poldini L, Oriolo G, Vidali M (2001). Vascular flora of Friuli-Venezia Giulia. An annotated catalogue and synonimic index. Studia Geobotanica 21: 3-227.

Popescu SC, Wynne RH, Nelson RF (2002). Estimating plot-level tree heights with lidar: local filtering with a canopy-height based variable window size. Computers and Electronics in Agriculture 37: 71-95. - doi: 10.1016/S01681699(02)00121-7

Popescu SC, Wynne RH (2004). Seeing the trees in the forest: using lidar and multispectral data fusion with local filtering and variable window size for estimating tree height. Photogrammetric Engineering \& Remote Sensing 70 (5): 589-604. [online] URL: http://asprs.org/a/publications/ pers/2004journal/may/2004_may_589-604.pdf

Raunkiær C (1934). The life forms of plants and statistical plant geography. Oxford University Press. [INCOMPLETE]

Reitberger J, Krzystek P, Stilla U (2008). Analysis of full waveform LIDAR data for the classification of deciduous and coniferous trees. International Journal Of Remote Sensing 29: 1407 1431. - doi: 10.1080/01431160701736448

Reitberger J, Schnorr C, Krzystek P, Stilla U (2009). 3D segmentation of single trees exploiting full waveform LIDAR data. ISPRS Journal of Photogrammetry and Remote Sensing 64: 561-574. - doi: 10.1016/j.isprsjprs.2009.04.002 Rowell E, Seielstad C, Vierling L, Queen L, Shepperd W (2006). Using laser altimetry-based segmentation to refine automated tree identification in managed forests of the Black Hills, South Dakota. Photogrammetric Engineering \& Remote Sensing 72 (12): 1379-1388. [online] URL: http://courses.washington.edu/cfr530/reading2a.pdf

Saatchi SS, Harris NL, Brown S, Lefsky M, Mitchard ETA, Salas W, Zutta WR, Buermann W, Lewis SL, Hagen S, Petrova S, White LEE, Silman M, Morel A (2011). Benchmark map of forest carbon stocks in tropical regions across three continents. Proceedings of the National Academy of Sciences USA 108: 9899-9904. doi: $10.1073 /$ pnas. 1019576108

Serra J (1982). Image analysis and mathematical morphology. Vol I. Image Processing. Academic Press, London, UK, pp. 610.

Serra J (1988). Image analysis and mathematical morphology. Vol II. Theoretical Advances. Aca- 
demic Press, London, UK, pp. 610

Shannon CE, Weaver W (1949). The mathematical theory of communication. University of Illinois Press, Urbana, USA

Simard M, Pinto N, Fisher JB, Baccini A (2011). Mapping forest canopy height globally with spaceborne LiDAR. Journal of Geophysical Research-Biogeosciences 116: G04021 - doi: 10.1029/2011JG001708

Straub C, Dees M, Weinacker H, Koch B (2009). Using airborne laser scanner data and CIR orthophotos to estimate the stem volume of forest stands. Photogrammetrie Fernerkundung Geoinformation 3: 277-287. - doi: 10.1127/0935-1221/ 2009/0022

Straub C, Koch B (2011). Enhancement of bioenergy estimations within forests using airborne laser scanning and multispectral line scanner data. Biomass and Bioenergy 35: 3561-3574. doi: 10.1016/j.biombioe.2011.05.017

Ter Braak CJF (1986). Canonical correspondence analysis: a new eigenvector technique for multivariate direct gradient analysis in ecology. Ecology 67: 1167-1179. - doi: 10.2307/1938672 Ter Braak CJF (1988). Canoco an extension of decorana to analyze species-environment relationships. Vegetatio 75: 159-160.

Tonolli S, Dalponte M, Vescovo L, Rodeghiero M, Bruzzone L, Gianelle D (2011a). Mapping and modeling forest tree volume using forest inventory and airborne laser scanning. European Journal of Forest Research 130: 569-577. - doi: 10.1007/s10342-010-0445-5

Tonolli S, Dalponte M, Neteler M, Rodeghiero M, Vescovo L, Gianelle D (2011b). Fusion of airborne LiDAR and satellite multispectral data for the estimation of timber volume in the Southern Alps. Remote Sensing of Environment 115: 2486-2498. - doi: 10.1016/j.rse.2011.05.009

Tickle PK, Lee A, Lucas RM, Austin J, Witte C (2006). Quantifying australian forest floristics and structure using small footprint LiDAR and large scale aerial photography. Forest Ecology and Management 223: 379-394. - doi: 10.1016/ j.foreco.2005.11.021

Van Leeuwen M, Nieuwenhuis M (2010). Retrieval of forest structural parameters using LiDAR remote sensing. European Journal of Forest Research 129: 749-770. - doi: 10.1007/s10342010-0381-4
Verrelst J, Gertjan WG, Sykora KV, Clevers JGPW (2009). Mapping of aggregated floodplain plant communities using image fusion of CASI and LiDAR data. International Journal of Applied Earth Observation and Geoinformation 11: 83-94. - doi: 10.1016/j.jag.2008.09.001

Vetaas O (1997). The effect of canopy disturbance on species richness in a central Himalayan oak forest. Plant Ecology 132: 29-38. - doi: 10.1023/ A: 1009751219823

Vierling KT, Vierling LA, Gould WA, Martinuzzi S, Clawges RM (2008). Lidar: shedding new light on habitat characterization and modelling. Frontiers in Ecology and The Environment 6: 9098. - doi: 10.1890/070001

Westhoff V, Van Der Maarel E (1978). The Braun-Blanquet approach. In: "Classification of plant communities" (Whittaker RH ed). Junk, The Hague, The Netherlands, pp. 287-297. Winjum JK, Dixon RK, Schroeder PE (1992). Estimating the global potential of forest and agroforest management practices to sequester carbon. Water, Air and Soil Pollution 64: 213-228. - doi: 10.1007/BF00477103 